\author{
O. V. Dolzhykova, L. M. Maloshtan \\ National University of Pharmacy
}

\title{
PATHOMORPHOLOGICAL RESEARCH OF VAGINAL SUPPOSITORIES “MELANIZOL” AGAINST IRRITATIVE VAGINITIS
}

The article considers the pathomorphological studies of the effect of vaginal suppositories "Melanizol" on the irritative vaginitis caused by a mixture of turpentine and dimethylsulfoxide in rats. Vaginal suppositories "Melanizol" showed a therapeutic effect on the vaginitis, which manifested by preventive the occurrence of necrotic-inflammatory lesions, and promoted the healing of defects in mucosal and submucosal layer of the vaginal wall. Low positive therapeutic effect of suppositories "Gravagin" on the state of the vaginal wall of female rats on the model of experimental vaginitis has been proven. Sufficiently large foci of destruction of the vaginal wall, foci of inflammation, edema of collagen fibers of rats vaginal wall of this group was present. Vaginal suppositories "Melanizol" are perspective for using as a drug for the treatment of nonspecific vaginitis with destructive reaction and inflammation.

Key words: pathological studies; vaginal suppositories; tea tree oil; metronidazole

\section{INTRODUCTION}

Infectious-pelvic inflammatory disease is an urgent medical and social issue of Obstetrics and Gynecology [1, 3, 8].

Vaginal infections are very common, especially among women of reproductive age. Prevalence in pregnant women is $13.08 \%$, it can lead to significant negative effects, complications of childbirth and fetal infections [9]. Despite the fact that they do not result in high mortality rates, these infections are associated with high levels of anxiety and reduced quality of life [11] and is the cause of most outpatient gynecologic visits. A mixed infection is the most common cause. Ordinary therapies cause shortterm effect, frequent relapses and increasing resistance of micro-organisms are unsolved problems. In addition, vaginal infections are associated with a variety of serious adverse outcomes during pregnancy and in general have a significant impact on quality of life. The correct treatment can be a challenge for the clinician, especially in mixed infections [10].

Metronidazole is antibacterial drugs with anti-anaerobic activity effective for the treatment of vaginal infections. It is known that the metronidazole can be used effectively in various forms for treatment of vaginal infections. However, oral administration of this drug often causes side effects such as metallic taste in the mouth, dyspeptic disorder, allergic reactions. A long period of its application may develop so-called neuropathic syndrome and hypersensitivity [2].

In most cases the topical treatment of vaginal infections is as effective as oral treatment that results in a

(c) Dolzhykova O. V., Maloshtan L. M., 2016 higher local concentration of the drug, with fewer drugdrug interactions and side-effects. In addition, the emergence of microbial resistance and difficulties in the management of recurrent infections to support the need for more effective a drugs containing plant material [11].

Therefore, study the impact of new vaginal suppositories "Melanyzol" [5] based on metronidazole and tea tree oil on morphological status vaginal mucosa against the background of the experimental irritative vaginitis is very interested. The vaginal suppositories "Melanyzol" developed by employees of TL department of NUPh.

\section{MATERIALS AND METHODS}

The research was conducted on white female rats nonlinear. Irritative vaginitis was modeled by mixture of terebenthine oil with dimethylsulfoxide in a ratio of $1: 1$ vaginally [6].

The females estrous cycle was investigated and selected animals in oestrus-prooestrus phases before the experiment to minimize differences in the assessment of the functional state of the mucous membrane of the vagina for comparing the results. Animals were divided into groups: 1-st group - intact animals, 2-nd group - control pathology (positive control), 3 group - animals treated with vaginal suppositories "Melanizol", 4 group - animals treated with the comparator vaginal suppositories "Gravagin"; 5 group - animals treated with suppository base (placebo) in the equivalent amount (negative control). Administered doses of investigated suppository counted by used in experimental pharmacology method of species stability of Yu. R. Rybolovlev [7].

Vaginitis treatment began on the first day of disease and continued for 8 days. The animals were sacrificed 

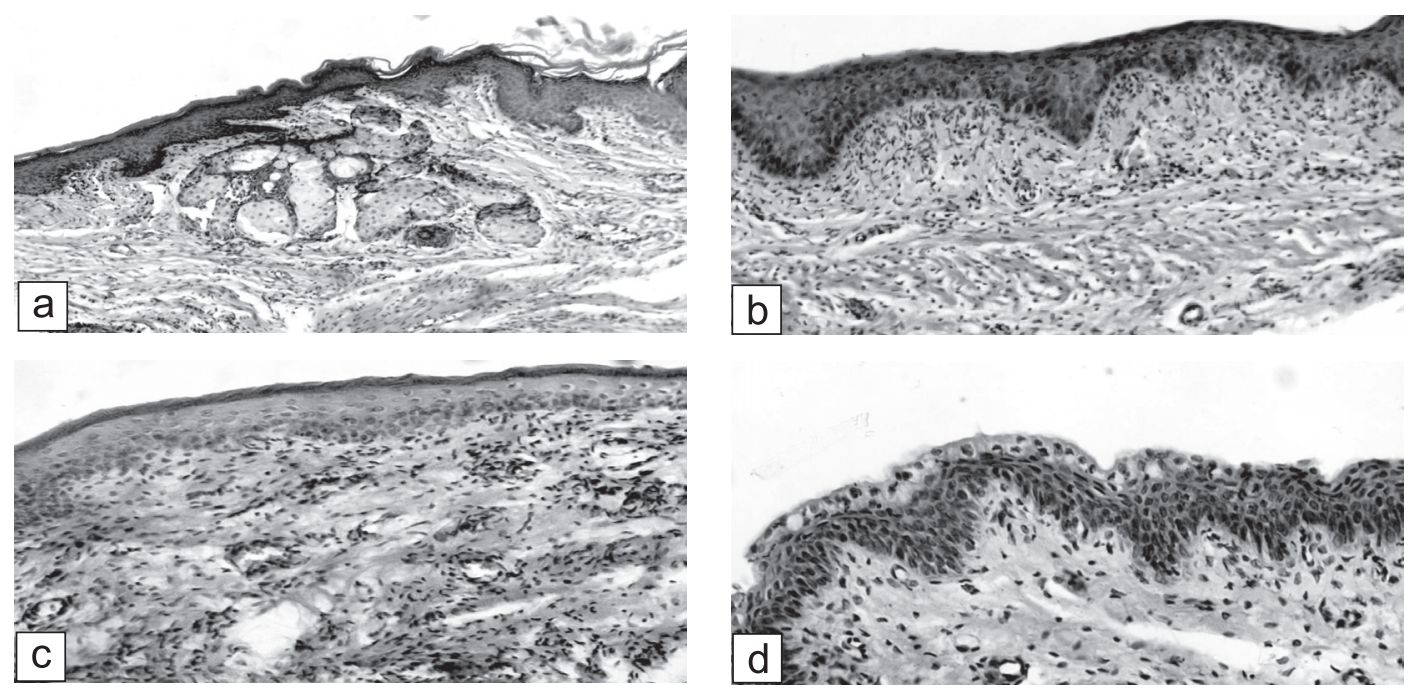

Fig. 1. The epithelium of various parts of mucous membrane of wall of the vagina intact female rats: $a$-vestibule of vagina (typical school); $b$-distal part (multilayered keratinized); $c$ - $d$ - proximal part (phase oestrus, prooestrus). Hematoxylin-eosin. $a-c-x 100, d-x 200$

on the 5-th and 8-th day from the beginning of the experiment by method of euthanasia. After autopsy of animals vaginal mucosa were studied by macroscopic method and vaginal samples was removed and processed for routine histological study [4]. The analysis of microphotographs were performed under the microscope Granum, microscopic image was taken digital video camera Granum DSM 310. Photos processed on a computer Pentium 2,4GHz with using Toup View.

Histological study did with the consulting of Senior Researcher Yu. B. Lar'yanovskaya.

\section{RESULTS AND DISCUSSION}

The wall of the vagina of intact control animal consists of mucous, muscular and adventive layers in the microphotographs. Structural organization of epithelial mucosa in different parts of the vaginal wall is somewhat varied. In the vestibule of vagina is a typical skin type. At the distal (tail vagina) is multilayer flat epithelium with keratinized symptoms (called transitional type). Basal and intermediate layers were well differentiated and traced moderate dipping of epithelial tongues deep into mucosa. In the proximal part (close to the odd part of the uterus) epithelial structure depended on the phase of the estrous cycle. In the microphotographs in phase prooestrus epithelium was a multilayered-prismatic with mucinous cells on the surface, in the oestrus phase it was multilayered flat keratinized epithelium. The stratum corneum is expressed very moderate (less expressive than in the distal). It should be noted that often in different microphotographs observed different stages of development phases prooestrus-oestrus, which differ among themselves by severity of features. Vaginal mucosa lamina propria (stroma) had features of dense connective tissue. Closer to the muscle layer is changed in the submucosal layer, which looked like loose connective tissue. Vascularization was normal, the lumen of blood vessels was free and moderately wide. Submucosal layer directly changed in the muscle layer. Adventive layer is located outside of the muscle layer, consisted of loose connective tissue containing blood vessels (Fig. 1).

On the fifth day after administration of a mixture irritants in $87.5 \%$ of females observed widespread destructive inflammatory changes all layers of the vaginal wall. The mucous layer is in a state of complete destruction, heavily infiltrated by mononuclear cells. Submucosal layer is very edematic, enlarged, collagen fibers altered degenerative, inflammatory cell response is located closer to the muscular layer. The blood vessels of the stroma mucous layer and submucosal layer paralytic expanded, in some of their observed blood cells located on the edge (Fig. 2a).

The vagina epithelial layer of other animals was saved, but without differentiation layers, superficial epithelium layer was in the state of the morphologic alterations, sometimes whole layer started to exfoliate off completely and stroma at this place was without outer layer. Collagen component of the lamina propria of mucous layer was very edematic. The stroma was penetrated by red blood cells, expressive inflammatory reaction was in the submucosal layer (Fig. 2b).

In areas beyond the destructive changes observed stromal mucosal edema, inflammation in the submucosal layer. The epithelium, on the whole, kept the ability to physiological changes (phase rrooestrus-oestrus). At the same time, in the epithelial layer you can see the proliferation of basal cells, degeneration cell of the intermediate layer, sometimes layer lost the typical cells location (Fig. 3a). In some places you can see proliferation of epithelial (Fig. 3b).

Thickening of the epithelial layer, hyperkeratosis, acanthosis is present in the distal part of the mucous 

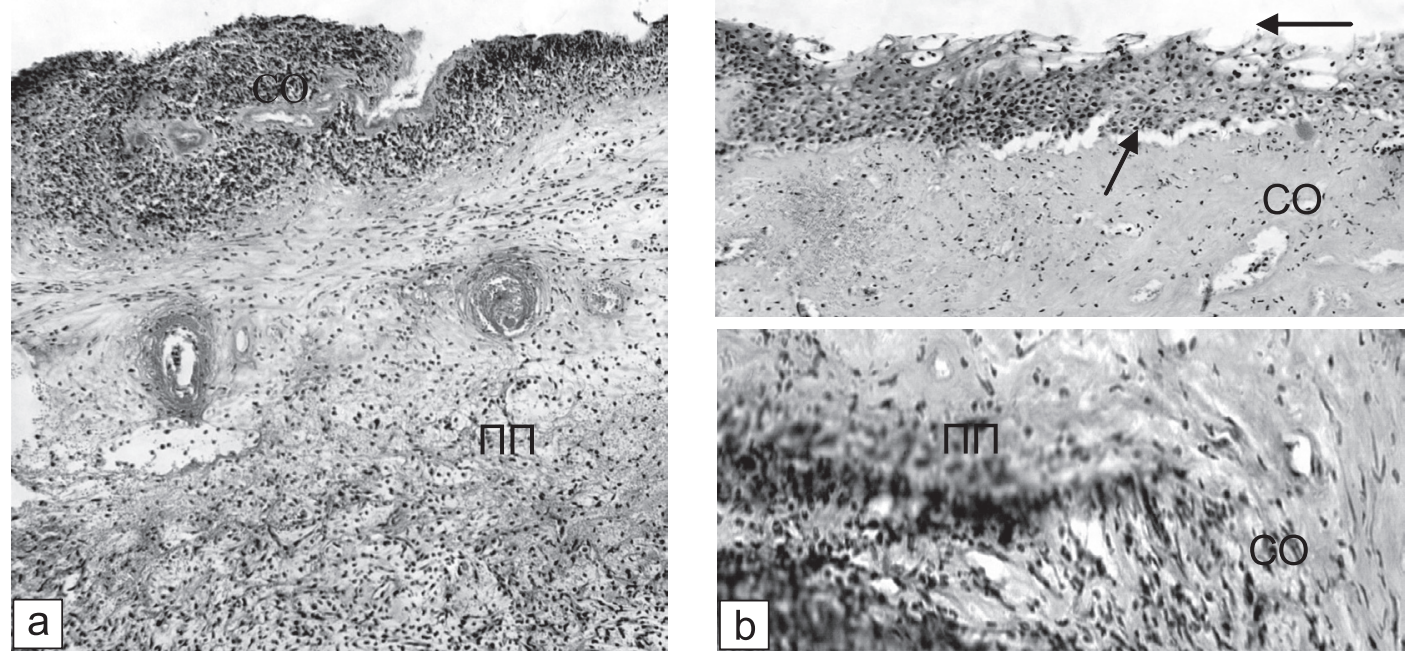

Fig. 2. The wall of the vagina of female rats on the 5-th day after administration of a mixture irritants: a-necrosis with mononuclear infiltration of mucous layer (CO), edema, degeneration of collagen fibers of submucosal layer (ПП), paralysis of the vascular wall, inflammatory reaction; $b$ - necrobiosis of the surface layers of the epithelium, absence of layers differentiation, exfoliation of layer, stroma of mucous is without outer layer and with edema (CO), erythrocyte penetration. Inflammation of submucosal layer (ПП). Hematoxylin-eosin. x100
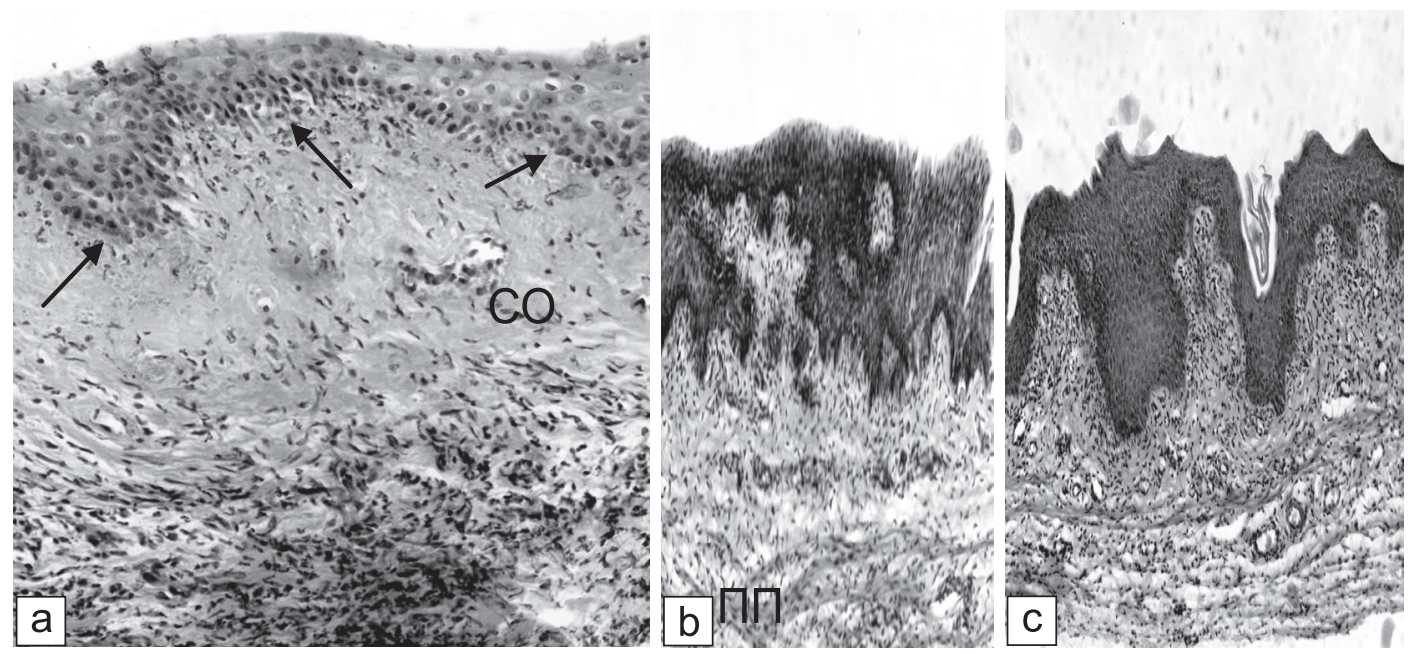

Fig. 3. The wall of the vagina of female rats on the 5-th day after administration of a mixture irritants. The area beyond the zone of destruction: a - proliferation of basal cells (arrows), degeneration of cells intermediate layer of the epithelium, edema of stroma mucous membrane (CO), inflammatiory cell reaction in the submucosal layer (ПП); $b$-expressive proliferation of epithelial layer. Hematoxylin-eosin. x200; c-distal part (thickened epithelial layer, hyperkeratosis, inflammation in the stroma. Hematoxylin-eosin. x100

layer, and you can see mild inflammation in the stroma of mucous layer (Fig. 3c).

On the 8-th day of the experiment pathologycal changes in mucous membrane of the vagina in control group were insignificant. Epithelial structure and physiological cycle were without changes. Plethoric capillary network noted in proximal subepithelial mucous layer some females, small focal hemorrhages, inflammation remains. In places of the distal part epithelial layer thickening, hyperkeratosis were saved (Fig. 4a, b, b ${ }^{1}$ ).

Administration of vaginal suppositories "Melanizol" on the 5th day after using irritants prevented the occur- rence of destructive changes and manifestations of inflammation in the vaginal mucosa in $75 \%$ of female rats. Morphology typical phases of the estrous cycle unchanged. In the submucosal layer of some females the remains of focal inflammatory responses were found (Fig. 5).

In one female $(12.5 \%)$ microdefect of mucosa was healed almost traced. Its surface is lined with a single row of regenerated epithelium, the edges of which (top) shows an old dystrophic epithelial layer. Under regenerated epithelium, stroma still swollen, but inflammation and vascular reaction in the submucosal layer sufficiently clearly reduced (Fig. 6a). Epithelium in the adjacent segments, 

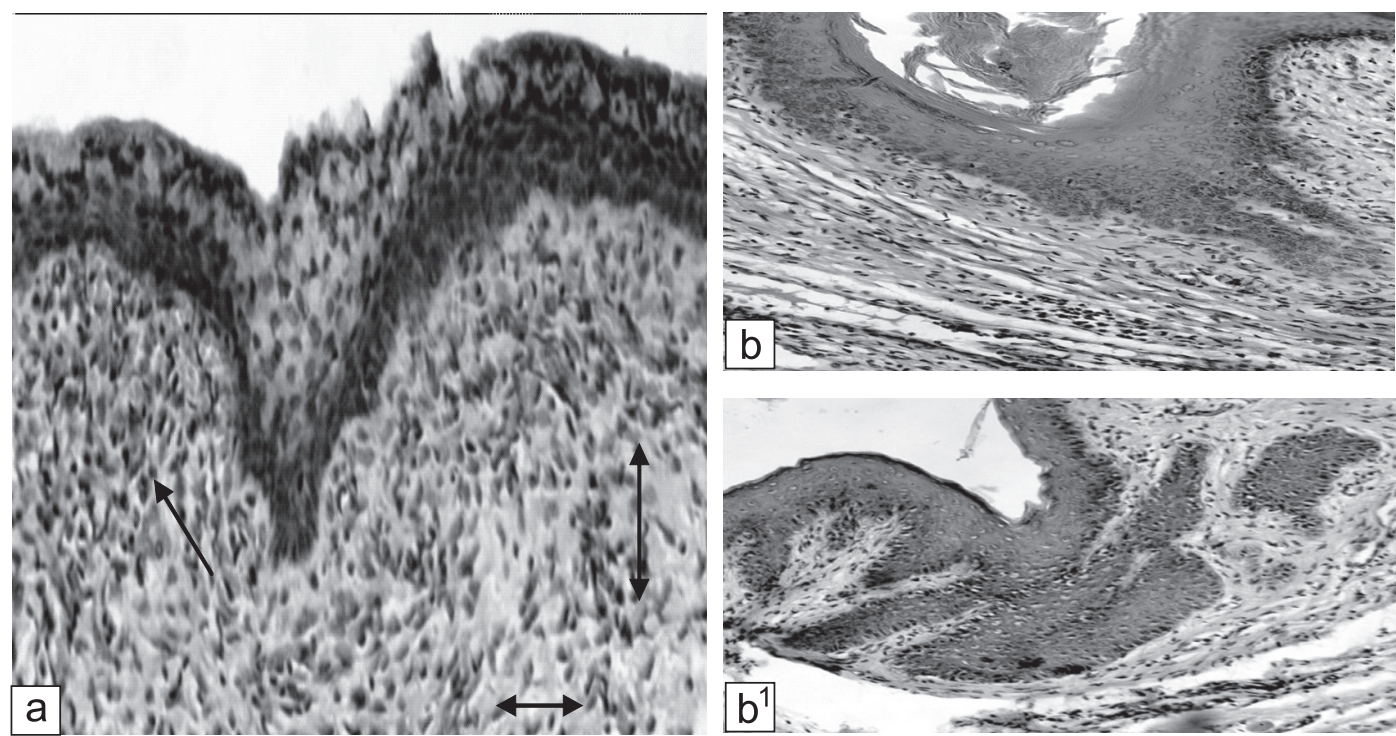

Fig. 4. The wall of the vagina of female rats on the 8-th day after administration of a mixture irritants. Proximal part: a - normal state epithelium, remains of inflammation in the stroma, small subepithelial hemorrhage (arrow), expansion and plethoric of capillary network (x250). Phase prooestrus. Distal part: b-thickened epithelial layer, hyperkeratosis (x200). Phase oestrus. Hematoxylin-eosin
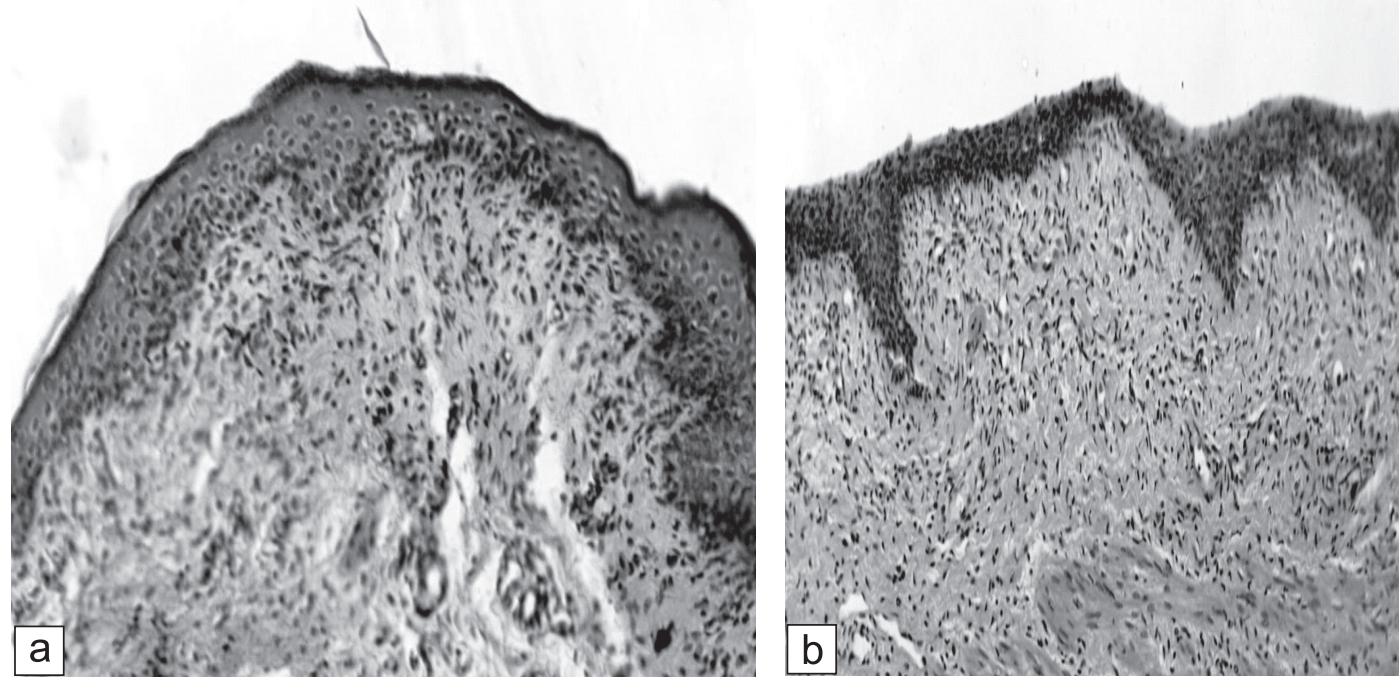

Fig. 5. The wall of the vagina of female rats treated with vaginal suppositories "Melanizol" on the 5-th day after administration of a mixture irritants. Good state of mucous leyer of in the distal (a, x250) and proximal (b, x200) part. Phase oestrus. Hematoxylin-eosin

which cover a surface, is thickened. One female in destructive changes in vaginal mucosa were rather common. However, in contrast to control disease, defect of large areas was cleared from cell detritus, edema and degenerative modified collagen fibers of the stroma of the mucous layer mostly seen only. In the submucosal layer expressive inflammatory cell infiltration and significantly lower vascular response was traced compared with the control pathology (Fig. 6c).

On the 8-th day of the experiment all animals $100 \%$ changes in the vaginal wall were absent, microscopic view phase oestrus and prooestrus cycle was typical (Fig. 6).
After using the vaginal suppositories "Gravagin" on the background of administration irytants $50 \%$ of ratfemales it has been fouded very large cell destruction of vaginal wall that spread deep to mucosa and submucosal layer. Inflammation, edema of collagen fibers were registered in the stroma mucosa under necrotic masses. A massive proliferation of the epithelium until submucosal layer, distruction of differentiation layers, dystrophy cells were seen often on the border of destruction (Fig. 7a). $25 \%$ of the animals had not damaged surface epithelium, but the lamina propria mucosa was with edema collagen component and a lot of haemorrhages 

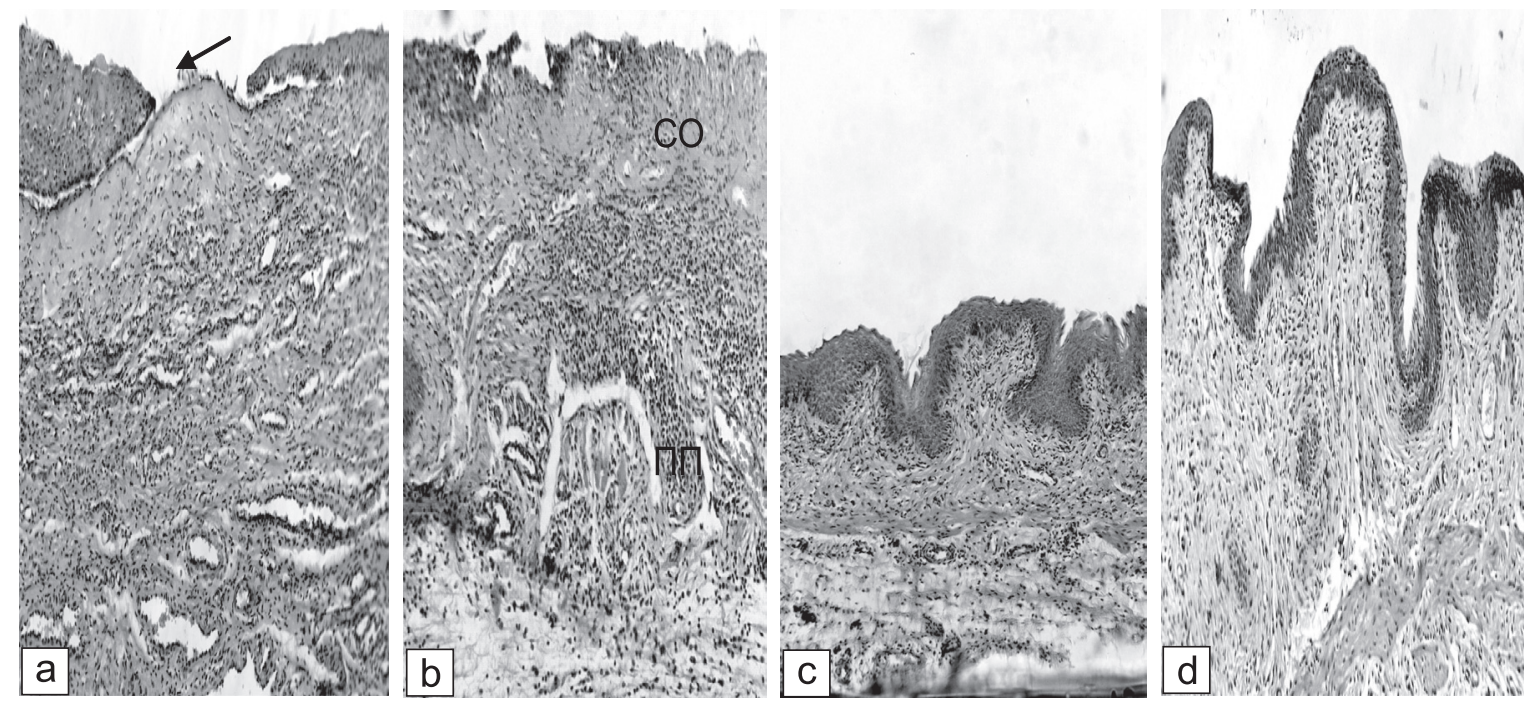

Fig. 6. The wall of the vagina of female rats treated with vaginal suppositories "Melanizol". On the 5-th day after administration of a mixture irritants: $a$ - micro-defects healed; $b$ - common defect (edema of the mucous layer stroma (СО), inflammation in submucosal layer. (ПП), reducing vascular reaction). On the 8-th day after administration of a mixture irritants: $b$ - the normal state of the distal part of mucous laer (phase oestrus); $d$ - proximal part (phase prooestrus). Hematoxylin-eosin. a, $c-x 100 ; b, d-x 200$
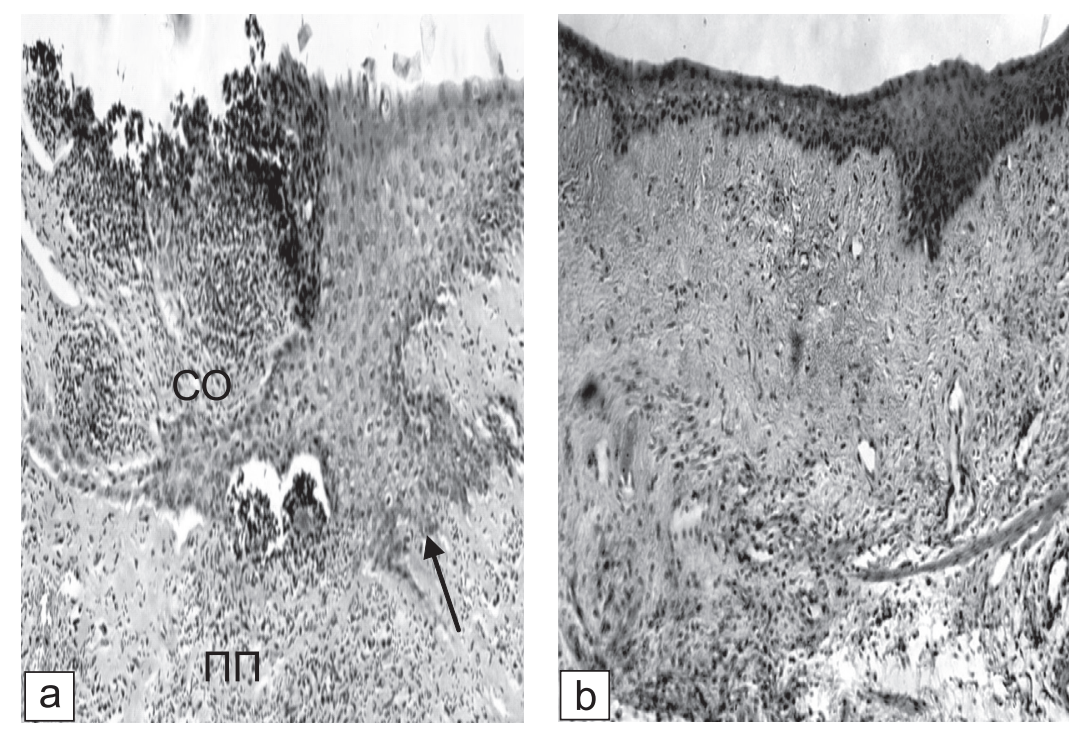

Fig. 7. The wall of the vagina of female rats treated with vaginal suppositories "Gravagin" on the 5-th day after administration of a mixture irritants: a - center of destruction of mucous layer (CO) and submucosal layer (ПП), hypertrophic proliferation of the epithelium on the edge of destructive zone (arrow); $b$ - edema, penetration lamina propria of mucous membrane by erythrocytes under intact epithelium. Hematoxylin-eosin. x100

(Fig. 7b). Only $25 \%$ of rat-females had typical structure of vaginal wall mucosa (Fig. $7 \mathrm{c}$ ).

On the background of placebo administration during 5 days of the experiment vaginal wall of rats practically do not have positive changes compared to the control pathology. On the 8-th day, as in the control pathology group was a natural regression of pathological process.

\section{CONCLUSIONS}

1. Vaginal suppositories "Melanizol" on the model of irritatsve vaginitis caused by a mixture of tereben- thine oil and dimexide discovered therapeutic effect which manifested by prevention of necrotic-inflammatory damage and promoting healing of defects mucous membrane of and submucosal layer of the vaginal wall.

2. On experimental vaginitis models referes suppositories "Gravagin" were inferior for the expressiveness of positive effect on the state of the vaginal wall of female rats that was manifested in the presence of sufficiently large cell destruction of vaginal wall, inflammation, edema of collagen fibers. 
3. Vaginal suppositories "Melanizol" is perspective for using as a drug for the treatment of nonspecific vaginitis with destructive and inflammatory reactions.

\section{REFERENCES}

1. Авраменко Н. В. Воспалительные заболевания органов малого таза у женщин как ведущий фактор формирования трубно-перитонеального бесплодия / Н. В. Авраменко // Запорожский мед. журн. - 2014. - № 4 (85). - С. 63-68.

2. Ефимов Б. А. Бактериальный вагиноз: современный взгляд на проблему: [Электронный ресурс] / Б. А. Ефимов, В. Л. Тютюнник // РМЖ. - 2008. № 1. - С. 18. Режим доступа: http://www.rmj.ru/ articles/pediatriya...

3. Золотов И. С. Терапия воспалительных заболеваний женских половых органов: возможности иммуномодуляторов / И. С. Золотов, В. В. Остроменский // Гинекол. - 2012. - Т. 13, № 3. - С. 86-90.

4. Меркулов Г. А. Курс патологогистологической техники / Г. А. Меркулов. - М.: Медицина, Ленингр. отд-ние, 1969. - 424 с.

5. Пат. 96646 України МПК (2011.01), А 61 К 9/02, А 61 К 31/4164, А 61 К 36/61, А 61 Р 15/00 Протизапальний засіб у формі песаріїв з метронідазолом і олією чайного дерева: / Т. Г. Ярних, Ю. В. Левачкова, Л. М. Малоштан, К. О. Степанова; заявник та патентовласник Національний фармацевтичний університет. - № а 201001 134. - Заявл.: 04.02.2010. Опубл.: 25.11.2011. - Бюл. № 22. - 3 с.
6. Пат. 95741 України МПК (2006.01), А 61 К 31/565, А 61 К 31/197, А 61 К 9/02, А 61 P 15/08, А 61 P 15/12 Фармацевтична композиція для лікування захворювань урогенітальних органів / А. Ю. Рудько, А. В. Солнцева, Л. А. Усоєва, Л. В. Моругіна; заявник та патентовласник Открытое акционерное общество «Нижегородский химико-фармацевтический завод». - № а201010120. - Заявл.: 16.08.2010. Опубл.: 25.08.2011. - Бюл. № 16. - 11 с.

7. Рыболовлев Ю. Р. Дозирование веществ для млекопитающих по константам биологической активности / Ю. Р. Рыболовлев, Р. С. Рыболовлев // Докл. АН СССР, 1979. - Т. 247. - № 6. - С. 1513-1516.

8. Aboualigalehdari E. Anti-biofilm Properties of Peganum harmala against Candida albicans / [E. Aboualigalehdari, N. Sadeghifard, M. Taherikalani et al.] // Osong Public Health Res. Perspect. - 2016. - Vol. 7 (2). - P.116-118.

9. Dermendjiev T. Epidemiological, clinical and microbiological findings in women with aerobic vaginitis / T. Dermendjiev, B. Pehlivanov, K. Hadjieva, S. Stanev // Akush. Ginekol. (Sofiia). - 2015. - Vol. 54 (9). - P. 4-8.

10. Palmeira-de-Oliveira R. Palmeira-de-Oliveira R. New strategies for local treatment of vaginal infections / R. Palmeira-de-Oliveira, A. Palmeira-de-Oliveira, J. Martinez-de-Oliveira // Adv. Drug. Deliv. Rev. - 2015. Vol. 92. - P. 105-122.

11. Mendling W. Use of locally delivered dequalinium chloride in the treatment of vaginal infections: a review / [W. Mendling, E. R. Weissenbacher, S. Gerber et al.] // Arch. Gynecol. Obstet. - 2016. - Vol. 293. - P. 469-484. 
УДК 615.454.2:618.15-002:616-08

Е. В. Должикова, Л. Н. Малоштан

\section{ПАТОМОРФОЛОГИЧЕСКОЕ ИССЛЕДОВАНИЕ ВАГИНАЛЬНЫХ СУППОЗИТОРИЕВ «МЕЛАНИЗОЛ» НА ФОНЕ ИРРИТАТИВНОГО ВАГИНИТА}

Представлены патоморфологические исследования влияния вагинальных суппозиториев «Меланизол» на ход ирритативного вагинита, вызванного смесью живичного скипидара и диметилсульфоксида у крыс. Вагинальные суппозитории «Меланизол» на фоне вагинита проявили лечебный эффект, который проявился в предотвращении возникновения некротически-воспалительного повреждения и в способствовании заживлению дефектов слизистой оболочки и подслизистого слоя стенки влагалища. На модели экспериментального вагинита было доказано, что суппозитории «Гравагин» по выразительности положительного влияния на состояние влагалищной стенки крыс-самок уступали суппозиториям «Меланизол», что проявлялось в наличии достаточно крупных очагов деструкции влагалищной стенки, очагов воспаления, отека коллагеновых волокон. Вагинальные суппозитории «Меланизол» являются перспективными для применения в качестве препарата для лечения неспецифических вагинитов, сопровождающихся деструктивно-воспалительными реакциями.

Ключевые слова: патоморфологические исследования; суппозитории вагинальные; масло чайного дерева; метронидазол

\section{УДК 615.454.2:618.15-002:616-08 \\ о. В. Должикова, Л. М. Малоштан \\ ПАТОМОРФОЛОГІЧНЕ ДОСЛІДЖЕННЯ ВАГІНАЛЬНИХ СУПОЗИТОРІЇВ «МЕЛАНІЗОЛ» НА ТЛІ ІРИТАТИВНОГО ВАГІНІТУ}

Представлені патоморфологічні дослідження впливу вагінальних супозиторіїв «Меланізол» на перебіг іритативного вагініту, викликаного сумішшю живичного скипидару і диметилсульфоксиду у щурів. Вагінальні супозиторії «Меланізол» на тлі вагініту виявили лікувальний ефект, який проявився у запобіганні виникненню некротично-запального пошкодження та у сприянні загоєнню дефектів слизової оболонки та підслизового прошарку стінки піхви. На моделі експериментального вагініту було доведено, що супозиторії «Гравагін» поступалися супозиторіям «Меланізол» за виразністю позитивного впливу на стан піхвової стінки щурів-самиць, що проявлялося у наявності достатньо великих осередків деструкцій піхвової стінки, вогнищ запалення, у набряку колагенових волокон. Вагінальні супозиторії «Меланізол» $є$ перспективними для застосування в якості препарату для лікування неспецифічних вагінітів, що супроводжуються деструктивно-запальними реакціями.

Ключові слова: патоморфологічні дослідження; супозиторії вагінальні; олія чайного дерева; метронідазол

Адреса для листування:

61002, м. Харків, вул. Куликівська, 12.

Національний фармацевтичний університет

Надійшла до редакції 13.09.2016 р. 